Church form of the Incarnation thus finds in the eucharist the supreme occasion of the expression of its governing life-principle of self-sacrifice. In the eucharist "offerers and offered are one, since both are modes of the body of Christ. When believers perform the eucharistic rite, they offer themselves in offering the elements. Further, Christ offers Himself as the believers offer the eucharistic sacrifice, since it is His humanity which the believers offer in offering themselves and the sacrifice." The eucharist is thus a making present in time of what is true in eternity.

In conclusion, Dr. Smedes offers a criticism of these ideas in the light of the Biblical witness. First, the Biblical doctrine of creation leaves us with an unavoidable impression that man, created in the image of God, was a completed being. So man did not need an Incarnation of God in order to fulfil his vocation of total worship. This cancels out the prevailing premiss of these writers as to the purpose of the Incarnation-that it was required by the nature of creation, and would have occurred even had not sin entered man's life. Second, according to the Bible, man's relation to God has been disrupted by the fall. So man's need of the Incarnation was religious, not metaphysical - a need of reconciliation not elevation, of meditation not metaphysical completion. This confirms the alternative premiss of Dr. Smedes that the Incarnation was solely the divine remedy for the evil brought into the world by man's fall into sin. The Biblical presentation of the Christ fits perfectly the Biblical presentation of the need.

Dr. Smedes consequently contends that such "modern Anglican Christology" as he has surveyed "has in common an unbiblical thesis as to the purpose of the Incarnation." It is dominated by the "tendency to rationalize the Incarnation by taking it out of its Biblical setting of creation, sin and redemption and putting it within a semi-speculatve setting of man's metaphysical incompletion."

Since such Anglo-Catholic thought and teaching are widely prevalent and have their own obvious attraction for the religiously and philosophically minded, it is of urgent practical importance that their fundamental errors should be both properly appreciated and properly answered. Dr. Smedes' thesis does both. Although written by an American, and published in Holland, it therefore merits particular attention in this country, not least by evangelical Anglicans, or by any engaged in work for God among young converts who are exposed to the obvious natural fascination of AngloCatholic thought and practice.

Oak Hill College,

London, N.14.

A. M. STIBbS.

\title{
UNPUBLISHED HYMNS BY CHARLES WESLEY
}

Among the autograph manuscripts of hymns by Charles Wesley which are in the custody of the Epworth Press, City Road, are five volumes of short hymns on the Gospels and the Book of Acts. They vary in length from 195 pages (Mark) to 555 pages (Acts).

In search of variant readings, I began to collate the hymns in manuscript with Volume ii of Short Hymns on Select Passages of Holy Scripture, first published in 1762, and with the supposedly definitive Poetical Works of 1868-72. To my surprise, I began to find hymns in manuscript which were not included in either publication. Among the hymns on the Gospel of Mark alone, there are 46 unpublished hymns or portions of hymns.

The Short Hymns are in the nature of brief devotional verse expositions; the following is typical, and one cannot help wondering why it was ever omitted; the text chosen for exposition is Mark xv, 39.

"How powerful our Redeemer's cries Which life in death impart,

Which open still the sinner's eyes, And pierce his echoing heart!

By faith I hear his speaking blood, His mangled form I see,

And know, This is the Son of God, Whose cries converted me."

Tyndale House,

Cambridge.

J. Dale.

The Ridley Press, Cambridge and St. Ives. 